\title{
The Role of Instructor Due Diligence in Volunteer Income Tax Assistance (VITA): Evidence From One University-Level Program
}

\author{
Christine Kuglin \\ Washington University \\ Amy Cardillo \\ Metropolitan State University of Denver
}

This paper reviews the tax preparation practice of one university-level Volunteer Income Tax Assistance (VITA) program to determine the role, if any, due diligence requirements for paid preparers should have on student preparers. The due diligence requirements as outlined in Circular 230 apply to paid preparers. The Volunteer Standards of Conduct are outlined in IRS publication 4012 and apply to VITA volunteers who are often students. This study analyzes the tax challenges faced by student prepares in a VITA program, and how the increased due diligence standards required of the IRS for paid preparers would be beneficial to the students participating in a VITA program. The study models tax return data to show the financial benefit application of due diligence standards would have for the Internal Revenue Service. The goal of this paper is to show the importance of higher due diligence standards, and we contribute to the literature by providing the first review of VITA tax preparation through the lens of paid-preparer due diligence requirements.

Keywords: due diligence, volunteers, students, VITA, Circular 230, preparers

\section{INTRODUCTION}

According to the Internal Revenue Service (IRS), a Volunteer Income Tax Assistance (VITA) / Tax Counseling for the Elderly (TCE) program "offers free tax help to people who generally make $\$ 54,000$ or less, persons with disabilities, the elderly and limited English speaking taxpayers who need assistance in preparing their own tax returns. IRS-certified volunteers provide free basic income tax return preparation with electronic filing to qualified individuals" (IRS, Free Tax Return Preparation for Qualifying Taxpayers, 2018). Since the inception of VITA, "numerous college and university accounting departments have adopted and participated in the...program as a community service activity for accounting students" (Quinn, 1995). As Blanthorne and Westin identify, participation in the VITA program provides students with an invaluable service learning opportunity that provides experiential learning and career-related experience (Westin, 2016).

Partnering of VITA with local colleges and universities provides many benefits to all, however, it raises concerns about due diligence requirements. According to Accounting Degree.com (2018), "accounting professors should obtain their CPA licensure for advanced placement," and "accounting professors have usually worked (or work) as accountants in the professional world before they teach on the college level" 
(para 2). Licensed professionals, a Certified Public Accountant (CPA) or an Enrolled Agent (EA), who are paid to prepare tax returns are governed by Treasury Department Circular No. 230 and are subject to preparer penalties as outlined in Title 26 of the US Code. As many accounting professors have worked in the profession prior to teaching, if working in tax preparation, they have already been subject to the due diligence requirements surrounding tax preparation.

VITA volunteers, who are not paid preparers, work under IRS publication 4961, which outlines the VITA volunteer standards of conduct and ethics. The due diligence requirements for paid preparers do not apply to VITA volunteers which creates a disconnect for those university professors who desire to teach their tax students proper tax preparation practice before the IRS. This paper reviews the experiences from one university-level VITA site as a case study on what implications due diligence standards, tax law changes and VITA requirements have on faculty, students and the community VITA partners.

\section{Due Diligence and Standards of Conduct}

Treasury Department Circular No. 230 (Rev. 6-2014) are the regulations that govern practice before the IRS. The circular begins by providing that "the Secretary of the Treasury may (1) regulate the practice of representatives of persons before the Department of the Treasury." Within $\S 10.0$, the circular provides the rules "governing the recognition of attorneys, certified public accountants, enrolled agents, enrolled retirement plan agent, registered tax return preparers, and other persons representing taxpayers before the Internal Revenue Service."

Section 10.2 further defines these professionals. A "certified public accountant means any (emphasis added) person who is duly qualified to practice as a certified public accountant in any state, territory or possession of the United States." As many university accounting professors are CPAs, or are aspiring to achieve CPA licensure, they would be regulated by circular 230 as, as a CPA, they are "duly qualified to practice as a certified public accountant."

Continuing through circular 230, the definition of registered tax preparer refers the reader to section 7701(a)(36) of the internal revenue code (IRC). Within the IRC, a tax return preparer "means any person who prepares for compensation ... any return or tax imposed by [Title 26 of the US Code] or any claim for refund of tax imposed by this title (Internal Revenue Code, 2018)." Those who are paid to provide services for taxpayers are further governed within Circular 230 to "exercise due diligence" (Department of the Treasury, 2014). From section 10.22, due diligence as to accuracy is to be applied to tax return preparation as well as to the determination of the correctness of information given to the practitioner. For tax returns with refundable credits (credits that refund money to the taxpayer even if the taxpayer has made no payment to the IRS), there are due diligence penalties. Treasury Regulation Section 1.6695-2 describes the due diligence requirements for returns with refundable credits and Head of Household filing status, which are summarized as follows on the IRS website (IRS, Refundable Credit Due Diligence Law, 2018):

- Complete and submit the Form 8867, Paid Preparer's Due Diligence Checklist

- Complete all the necessary worksheets or similar document showing how you computed each of the credits.

- Know the tax law and ask questions until you have all the information you need to determine eligibility for, and the amount of, the credits. In evaluating information provided by the taxpayer, the tax preparer is held to a standard of making reasonable inquiries, if a reasonable and well-informed tax preparer, knowledgeable in the law, would conclude that the information seems incorrect, inconsistent, or incomplete. Be sure to note the questions you asked and the answers your client gave you at the time of the interview.

- Keep a copy of all of the above, along with a record of how and when you obtained the information to determine eligibility for, and the amount of, the credits. You must also keep a copy of all the documents you reviewed and used to determine eligibility for and the amount of the credits.

Section $6695(\mathrm{~g})$ of the IRC provides that failure to abide by the due diligence requirements could result in penalties for the paid preparer of $\$ 540$ to $\$ 5000$ per error per return, depending on how egregious the error. 
In contrast, VITA participants must follow the Volunteer Standards of Conduct as described in IRS publication 4961. Within this publication, a volunteer must "not accept payment, solicit donations, or accept refund payments for federal or state tax return preparation." Additionally, the volunteer must not "knowingly prepare false returns" or "engage in criminal, infamous, dishonest, notoriously disgraceful conduct, or any other conduct deemed to have a negative effect on the VITA/TCE programs" (IRS, Pub 49612017 Returns, 2018). Failure to comply with these standards could result in the volunteer's removal from the program, deactivation of the sponsoring site's electronic filing number, and/or a referral of the conduct for potential Treasury Inspector General for Tax Administration (TIGTA) and criminal investigations (IRS, Pub 49612017 Returns, 2018).

When discussing concerns with VITA site coordinators about potential errors on VITA prepared returns and the level of due diligence as to accuracy, especially surrounding refundable credits or potentially fraudulent situations, the response is that the volunteers are protected by the Volunteer Protection Act of 1997 (Government Publishing Office, 1997). This act provides liability protection for volunteers:

no volunteer of a nonprofit organization or governmental entity shall be liable for harm caused by an act or omission of the volunteer on behalf of the organization or entity if -

(1) the volunteer was acting within the scope of the volunteer's responsibilities in the nonprofit organization ...at the time;

(2) if appropriate or required, the volunteer was properly licensed, certified, or authorized by the appropriate authorities for the activities or practice in the State in which the harm occurred;

(3) the harm was not caused by willful or criminal misconduct, gross negligence, reckless misconduct, or a conscious, flagrant indifference to the rights or safety of the individual harmed.

From the hold-harmless language in the Volunteer Protection Act, it is easy to assume that, if a student in a university-level VITA course is offering tax preparation services to the public, honest mistakes, not willful misconduct, would prevent punitive punishment. However, does the language in the Volunteer Protection Act protect the licensed professors? If a CPA or EA is guiding the students and a student fails to follow proper due diligence for the earned income tax credit (EITC), one of the refundable credits, could the licensed professor be held to the higher standards of Circular 230 and the due diligence requirements of the IRS? While these questions are beyond the scope of this paper and have also not been addressed in the courtroom, this paper does discuss the importance of instructor due diligence in the VITA classroom and the challenges university professors may encounter.

\section{Due Diligence and VITA}

The VITA program provides invaluable assistance to local communities. The Piton Foundation, a local foundation that oversees the VITA operations in Colorado, reports that the "Earned Income Tax Credit (EITC) is a refundable tax credit from the Internal Revenue Service (IRS) that helps boost the incomes of low-wage, working families. The EITC promotes work and is proven to reduce poverty by closing the gap between a family's income and what they need to make ends meet" (Piton Foundation, 2018). While community partners, instructors, and student volunteers are genuine in their desire to assist families to remain tax compliant, since the program's creation in 1969, income tax law has become increasingly complex. As a result, VITA participants are now responsible for many new tax credits and IRS forms, including:

American Opportunity Tax Credit - AOTC

This is an education credit for students in their first four years of post-high school education. A portion of this credit is refundable. (Internal Revenue Code Section 25A) 


\section{Lifetime Learning Tax Credit}

This is also an education credit that can be taken for students that do not qualify for the AOTC. This is not a refundable credit. (Internal Revenue Code Section 25A)

Earned Income Tax Credit - EITC

This is a refundable credit available for low to moderate income individuals. (Internal Revenue Code Section 32)

Child Tax Credit-CTC / Additional Child Tax Credit-ACTC / Orphan Drug Credit-ODC

These are all partially refundable credits for those taxpayers with qualified dependents. (Internal Revenue Code Section 24)

Schedule C Business Returns (No Specific Code Section)

A Schedule $\mathrm{C}$ must be filed if an individual is self-employed and his/her business is not a partnership or a corporation.

\section{Head of Household (HOH) Filing Status}

While not a new credit, the $\mathrm{HOH}$ filing status is among the checklist for due diligence requirements. In addition to these increased regulatory complexities, identity theft has become more problematic and widespread. According to Levin "the IRS investigations of tax-related identity theft are up 66\% since 2012" with the IRS identifying \$14.6 million false returns and stopping \$50 billion in fraudulent refunds (Levin, 2016).

Outside of tax law challenges, the VITA locations themselves present challenges to the university-led courses. The VITA programs are grant funded, so should faculty and student preparers work alongside IRS grant funded community partners, the IRS requires that return efficiency preparation be increased annually as part of the VITA grant awarding process. The Department of the Treasury VITA grant application requirements (IRS, VITA Grant Program Overview and Application Instructions, 2015), provides the following return preparation targets for grant recipients:

\section{Guiding Principle}

- Grant recipients are expected to show incremental increases (emphasis added) in return preparation each year.

\section{Measures of Success}

- Grant recipients are expected to achieve $100 \%$ of the return goal (emphasis added) specified in their grant agreements.

- Grant recipients are expected to become more efficient each year (emphasis added) with grant funds provided for their program. Any organization that received a grant in a prior year should prepare more returns with a similar amount of funding in the current year, reducing their cost of preparing returns.

Tax law challenges and return efficiency requirements increase the pressure and responsibility for assuring proper tax preparation at VITA sites. Such issues are making oversight and instruction of a university VITA program more onerous for accounting faculty, but to date there is limited available empirical evidence about the how such difficulties affect university-level programs, and as a result, little guidance on how faculty might address them.

\section{LITERATURE REVIEW}

Literature reviewed regarding VITA are largely written for an audience of educators. Literature regarding due diligence pertains to the paid preparers. This is understandable as VITA volunteers are, inherent within their title, volunteer, not paid preparers. Because of this distinction, we have been unable 
to find any literature that looks at the disconnect between VITA tax preparation standards and the standards placed before paid preparers.

In 2015, two articles were published in two different issues of Issues in Accounting Education. Anne Christensen and Angela Woodland wrote an article titled "Is Participation in the Volunteer Income Tax Assistance (VITA) Program Associated with Students' Problem-Solving Skills and Professional Commitment?" Cynthia Blanthorne and Stu Westin wrote an article titled "VITA: A Comprehensive Review of Literature and an Analysis of the Program in Accounting Education in the US." Blanthorne and Westin study various universities' utilization of the VITA program as a service-learning activity with a hope to revitalize the VITA program in the US. Christensen and Woodland study the impact on students who participate in VITA programs and conclude that, while involvement in VITA is positively associated with problem-solving skills, it is not associated with commitment to the profession.

A 2010 article by Davis, Harrison, and Turner offers practical guidance for establishing or improving a VITA program. This article cites the many journal regarding the service learning benefits of having a VITA program in conjunction with an institute of learning. They do caution about which returns to prepare, but the advice is to base it upon the site's mission and also to not compete with paid preparers. A 2013 article by Miller and Thalacker offers guidance of how to build an award winning VITA program through a case study of their own university's VITA site. They advise about location, site layout, hours of operation, and other items that are beneficial for any VITA site. They cite the importance of VITA programs in helping students intellectually and personally by increasing critical thinking skills, gaining practical experience, and engaging with diverse clients. The only advice for items to avoid are avoiding those returns that are outside of the VITA guidelines. A 2018 article by Christenson and Woodland examined relationship among VITA participation and ethical judgment and decision making. They found that VITA participation is positively and significantly associated with ethical judgment and, in certain cases, is also positively and significantly associated with ethical decision making.

While all of these VITA articles are excellent in showing the multitude of benefits of running a VITA program, they are limited in their practical application when it comes to due diligence requirements. They look at the educational benefit of the program but have failed to understand the importance of due diligence and the impact it has on paid preparers. While the VITA participants are volunteers, many of the student volunteers may wish to become paid preparers after completion of their university degree. Failure to hold students to the same due diligence standards as paid preparers fails to fully educate students on the ethical and legal obligations surrounding the practice of tax preparation that will be expected when hired into a professional career. This paper studies one university's VITA program and highlights the importance of requiring the students and professors to understand and follow the due diligence requirements.

\section{METHODOLOGY}

This paper uses the experiences from one university-level VITA site as a case study for exploring how recent changes in the social and regulatory tax environment are affecting the operation of VITA programs and what implications these have for accounting faculty, students and other stakeholders. Drawing on the experiences of faculty, students, and community partners and evidence from modeled and actual tax return data, the paper seeks to identify ways to improve the educational content of VITA programs by focusing on the importance given to due diligence and professional ethics by faculty coordinating such sites. The paper focuses on one VITA program as the authors were or are employed as faculty at the institution that runs this program. While the researchers could have conducted a survey of VITA coordinators, it was decided to present evidence from a single in-depth case study based upon one VITA program.

The VITA program at the subject university partners with the PITON foundation to secure funds, receive marketing for the available sites, and receive some administrative support. The university offers two courses that relate to VITA. The first is the course for undergraduate students who prepare income tax returns for VITA eligible clients. The second course is for graduate students. The graduate students help provide oversite and support for the course, including scheduling, tax preparation oversite, and tax return review. Each section of the course is open to 20 undergraduate students and two graduate students. The 
professor is the site coordinator, but will slowly train the graduate students to step into this role to further enhance their learning experience.

For this study, we observed and collected data from a spring semester, 2015 VITA site, focusing on all aspects of the return preparation process. We observed all aspects of the program, from the VITA client entering the site until the client left with a completed tax return. We identified tax issues that increased the difficulties associated with VITA tax return preparation, we highlighted the importance of due diligence at VITA sites, and we illustrated the impact of these issues by preparing a series of fictional tax return.

\section{ANALYSIS AND FINDINGS}

When attempting to understand the learning outcomes of university professors, many look to Blooms Taxonomy for an idea of the learning hierarchy. At the hierarchy's lowest level is knowledge or remembering, essentially asking if the student can recall or remember the information (Overbaugh, 1990s). The hierarchy's highest levels have the student achieving the ability to evaluate and create. Is the student able to "justify or stand on a decision" and, does the student have the ability to "create a new product or point of view" (Overbaugh, 1990s). If we apply these generalities to accounting students studying taxation, the professor's end-desire should be for the students to be able to justify and stand on tax decisions made. They should also be able to use their knowledge to enter the workforce and complete tax returns with differing information, using their ability to research and explore tax positions to come to their own points of view on how to most accurately reflect the tax information. However, to achieve this desired end-goal, the students must first be given the proper tax knowledge. A tax student first gains knowledge in his/her pre-requisite course on individual income taxation. The VITA course will then help move the student up the hierarchy into comprehension and understanding.

As provided in section 1.2 of this paper, students participating in the VITA course are responsible for knowing about many tax credits. In addition, they must consider the possibility of identity theft potentially perpetrated by their clients. Below are common tax situations experienced by the VITA students in our observations followed by our findings, which stress the importance of due diligence in helping students obtain the highest level of understanding.

\section{Credits}

\section{Earned Income Tax Credit and the Child Tax Credit}

In observations of the studied university VITA site, each student encountered a tax return with either an EITC, CTC or AOTC. These credits accounted for the majority of the tax refunds at the VITA site. The Treasury Inspector General for Tax Administration (TIGTA) stated in a 2013 VITA audit that $49 \%$ of the returns audited were prepared incorrectly (Berry, 2013). The IRS estimated that $24 \%$ of all EITC payments made in Fiscal Year 2013, or $\$ 14.5$ billion, were paid in error (Treasury Inspector General For Tax Administration (TIGTA), 2014). Before the EITC and CTCs can be claimed, VITA volunteers must first verify a client's identity. This is accomplished through presentation of a photo identification card at the time of return preparation. Secondly, the VITA volunteer must confirm filing status and dependency claims. Filing status and dependency claims are verified based upon the information supplied by the taxpayer, whether verbal or written. If a VITA taxpayer is claiming a dependent, they must bring a copy of the dependent's social security card. The last major item to be confirmed is income. Again, this is based upon information provided, written or verbal, by the taxpayer. There are also other factors to determine whether a taxpayer is eligible for these credits, depending on a taxpayer's specific situation. If more than one taxpayer may claim a dependent, or if a taxpayer was a non-resident alien for part of the year, will impact the eligibility of the credits.

Volunteers must go through a checklist of questions which sometimes may be complicated to answer. Some of the questions state "if the tie-breaker rules apply, would the child be treated as taxpayer's qualifying child?" or "was a taxpayer a nonresident alien for any part of the year?" It is not easy to say "yes" or "no" to the above questions because it involves technical terminology that an average person without tax experience may not understand (IRS, IRS Pub 4012, 2017). The answers to these questions will 
be critical in determining whether or not taxpayers are eligible to receive refundable credits. Due diligence and competency play an integral role in ensuring an accurate amount of EITC and CTC is claimed. While there is some training in this through the VITA 4012 manual, if the VITA instructor does not carefully prepare the students for these types of issues in a face-to-face client interview, the errors as described above can be extensive to the rate of the $49 \%$ error rate as stated by TIGTA (Berry, 2013).

While the review process of these credits may seem onerous at the volunteer level, section 1.2 of this paper described the requirements for paid preparers. While paid preparers must also verify filing status, dependency claims and income levels, merely relying on the taxpayer's verbal consent is not enough. More specifically, "the tax preparer is held to the standard of making reasonable inquiries, if a reasonable and well-informed tax preparer, knowledgeable in the law, would conclude that the information seems incorrect, inconsistent, or incomplete" (IRS, Refundable Credit Due Diligence Law, 2018). Additionally, a paid preparer must keep adequate notes and records to support the claims for refundable credits or be subject to fines (IRS, Refundable Credit Due Diligence Law, 2018).

It would seem reasonable to assume that students studying taxation wish to pursue tax preparation as a career. Many may also wish to pursue licensure to increase credibility within the field. As a professor desires for these students to be able to enter the workforce with the ability to prepare accurate returns and form substantiated tax positions taken, a professor would also be expected to have his/her students adhere to the more stringent due diligence requirements of Circular 230. While VITA sites refer back to the volunteer standards of conduct, those VITA sites that partner with university students should be expected to hold higher levels of due diligence as it should be inherent within the teaching practice.

\section{American Opportunity Tax Credit}

The observed VITA tax preparers also encountered tax returns with education tax credits. The AOTC allows students to receive up to $\$ 1,000$ in refundable credits and up to $\$ 1,500$ in non-refundable credits which can be used to offset tax liabilities. Utilizing data from Form 1098-T (Tuition Statement Required Qualified and Related Expenses), the AOTC is calculated based on the qualified tuitions and fees in excess of grants and scholarships. Recently, grants such as the Pell Grant and other non-tuition required funds can be redistributed to income to increase the amount of AOTC that can be refunded. This complicated calculation process is acknowledged by the IRS (Pell Grant Fact Sheet). The taxability of grants and scholarships requires VITA students to practice high due diligence and competence in order to compute correct refundable amounts. Again, failure to determine the accuracy of the information could, eventually, lead to fines and penalties levied against the taxpayer. Lower income individuals cannot afford fines and penalties, and fines and penalties due to poor tax return preparation done at a site designed to help these families is unethical.

\section{Potential Fraud}

In addition to the various credits, we also observed the VITA students being expected to handle potentially fraudulent situations. The IRS fraud handbook section 25.1.1.2 defines fraud as "deception by misrepresentation of material facts, or silence when good faith requires expression, which results in material damage to one who relies on it. Simply stated, it is obtaining something of value from someone else through deceit" (IRS, Part 25 Fraud Handbook, 2014). In order for fraud to be considered for prosecution, "the willful and material submission of false statements or false documents in connection with an application and/or return" (IRS, Part 25 Fraud Handbook, 2014) must be shown.

\section{Potential Fraud and Tax Credits}

The IRS website on the EITC provides: "IRS estimates that between 21 percent to 26 percent of EITC claims are paid in error. Some of the errors are unintentional caused by the complexity of the law, but some of the claims are intentional disregard of the law" (IRS, EITC and other refundable credits, 2017). We observed taxpayers changing their answers during the tax preparation phase in order to achieve a higher EITC. The IRS website asks paid preparers to report this suspected fraudulent activity on Form 3949-A. Within the VITA program, as discussed earlier, grant money is dependent upon the number of returns 
prepared. VITA sites wish to complete as many returns as possible to save their grant money while paid preparers wish to complete accurate returns in order to avoid potential penalties. Universities partner with local VITA grant recipients to offer tax preparation service. A university professor should desire to teach students at the highest level of due diligence and ethics but it could be in direct contrast with the desire of the local VITA partners as grant dollars may be at stake.

\section{Potential Fraud and Identify Verification}

The General Accountability Office's (GAO) 2016 annual report estimated that in the 2014 filing season, the IRS paid out approximately $\$ 3.1$ billion in fraudulent identify theft refunds (Government Accountability Office, 2016). At the VITA sites studied for this paper, students were observed handling potential identify theft issues. The area that brought many questions to the professor was the IRS "check the box" feature, which allows tax returns to be prepared for individuals who have W-2's with social security numbers that do not match their taxpayer identification number (ITIN). The IRS issues "ITINs to individuals who are required to have a U.S. taxpayer identification number but who do not have, and are not eligible to obtain a Social Security Number (SSN) from the Social Security Administration (SSA)" (IRS, General ITN information, 2018). These ITINS are for federal reporting only and the IRS issues these number to help individuals comply with U.S. tax laws (IRS, General ITN information, 2018). Taxpayer's with ITINs either provided a false social security number when filling in their I-9 employment verification form with their employer, or the employer knowingly hired an ineligible employee and provided the false social security number. Many taxpayer's wish to show "good moral character" when applying for U.S. citizenship, and one method to display this is through attempting to pay taxes owed. In order to file a tax return, the IRS suggests the following approach:

Tax returns filed with an Individual Taxpayer Identification Number reporting wages paid are required to show the Social Security Number under which the wages were earned. This creates an identification number (ITIN/SSN) mismatch. In the past, returns with this mismatch could only be filed on paper. Due to programming changes the IRS' e-file system can now accept these returns. The taxpayer's correct ITIN should be used as the identifying number at the top of Form 1040. When inputting W-2 information, the SSN should be entered exactly as shown on the Form W-2 issued by the employer. It is now possible to efile a return with an ITIN/SSN mismatch (IRS, ITIN reminders for Tax Professionals, 2018).

The IRS' desire to facilitate tax preparation with these documents exposes VITA volunteers to identity theft issues. Again, the VITA faculty supervisors, who may be EAs or CPAs and must adhere to Treasury Department Circular 230, are in the dilemma whether they should prepare returns with SSN/ITIN mismatches. The local VITA partners wish to process as many returns as possible to secure funding. The licensed faculty supervisor is cognizant of Section 10.51 in Circular 230, which provides:

Sec 10.51 - Incompetence or Disreputable Conduct Subject to Sanctions

- Giving any false or misleading information

- Willfully assisting others in the violation of any Federal tax law

It can be argued that completing a return with a fraudulent or stolen W2 could be considered as "willful assistance". While faculty supervisors desire to have good working relationships with their VITA community partners, the professor has an obligation to teach at the highest level of ethics and standards. Students wishing to become licensed tax return preparers should be taught the correct level of due diligence, the appropriate standards, the potential penalties that can be levied against return prepares, and the areas of potential fraud. If the highest level of learning from Bloom's Taxonomy is evaluation and creation, students should be taught to appropriately evaluate and question. The VITA program's desire to process as many returns as possible, coupled with the IRS' ITIN program, is in direct contrast to the IRS requirements outlined in Circular 230. 


\section{Analysis of VITA Tax Return Data}

We have identified a number of tax issues that both increased the difficulties associated with VITA tax return preparation and highlighted the importance of due diligence at VITA sites. In this section of the paper, we illustrate the impact of these issues by preparing a series of modeled tax returns to illustrate the potential for improperly prepared tax returns and then compare these to actual tax return data collected from VITA sites during 2015.

We modeled 37 tax returns with hypothetical data to illustrate the types of tax credits and refund values that could be generated at a VITA site and thus the dollar potential for error. Input data such as household sizes, annual adjusted gross incomes, dependents' information, and tuition and fees was entered to illustrate the amounts of refunds different households are able to claim. We examined how, when changing the number of household members, number of dependents and/or children, adjusted gross income, and data on many different issues could affect the refund amount. We used these modeled returns to compare to actual VITA returns from the 2015 tax year.

To analyze the correctness of our modeled tax returns, we used actual data on 2015 tax returns from an urban VITA site. It was aggregated into one report using the Statistical Data Details function in TaxWise Online Software, the IRS required VITA tax preparation software for tax year 2015. Confidential information in the report was removed. Analysis on the data was conducted to obtain a better understanding of the tax returns prepared at the sites and the associated refund totals. A random sampling was selected using the Excel RAND feature. Of the 632 tax returns downloaded, 281 were randomly generated. The data used for analysis was the total adjusted gross income (AGI) and total federal withholding, comparing this data to state and federal refunds. The highest refund at the VITA site was $\$ 11,396$ for the tax year of 2015 (49.62\% of AGI), which is comparable with the findings from the modeled returns. The highest refund to AGI percentage in the random sample was an AGI of $\$ 10,296$, federal withholding of $\$ 0$ and a combined state and federal refund of $\$ 6,835$ or a $66.91 \%$ refund to AGI ratio. Of the 281 returns in the sampling, 102 had $\$ 0$ federal withholding yet of these, only five owed taxes and the other 97 received refunds due to tax credits. Of the 282 returns, 222 received refunds in excess of $20 \%$ of their adjusted gross income. The median amount of refunds of those with $\$ 0$ federal withholding was $\$ 1,187$ and the average was $\$ 2,710$. We used a $\$ 0$ federal withholding to illustrate that these refunds are due entirely to refundable tax credits.

IRS VITA sites prepared over 3.7 million returns in 2015 with an average refund of \$2,700 (IRS, IRS Tax Volunteers, 2018). This translates into $\$ 9.99$ billion in total refunds generated in 2015 at VITA tax preparation locations. As previously provided, TIGTA reported that $49 \%$ of VITA returns were prepared incorrectly (Berry, 2013). While the report did not indicate how much of the $\$ 9.99$ billion in refunds was overpaid due to the $49 \%$ error rate, if we estimate that only $10 \%$ of these refunds were overpayments, this would equate to $\$ 990$ million in lost IRS revenue. Higher levels of due diligence could help mitigate the potential for error as well as the potential for fraudulent claims. It could also, potentially, help the IRS reduce the amount of lost revenue.

\section{Recommendations}

In this paper, we have analyzed the challenges faced by students and faculty at one university-level VITA program. Our findings suggest that an appropriate level of due diligence is essential for ensuring that the VITA site produces professional, high quality tax returns, and educates students to appreciate professionalism in the tax process; rather than speed and efficiency as required by IRS grant requirements. A lack of due diligence could substantially increase the risk for tax fraud, error, and identity theft.

From our experience, faculty instructors significantly influence the degree of due diligence that their students exercise. VITA students, after finishing the VITA program, may not remember how to complete the EITC worksheet or how to calculate qualified education expenses. However, lessons related to due diligence and care will stay with the students and become an invaluable professional skill and ingrained attitude. When students begin their career, they will realize that due diligence is an irreplaceable part of their professional ethics and duties. VITA students must practice the expected level of due diligence they need to exercise in order to maintain their reputations in the profession beyond that which is expected by volunteers. 


\section{CONCLUSION}

The due diligence requirements of paid preparers, as shown in this paper, can, at times, be in direct contrast to the requirements of volunteer preparers at VITA locations. It is understandable for the IRS to protect its volunteers under the Volunteer Standards of Conduct as it wishes to be able to provide a service to taxpayers without volunteers fearing IRS retribution. However, university accounting professors, many of whom are credentialed, must adhere to the higher level of ethics and due diligence that is required of their designations. Professors overseeing VITA sites filled with university students are not relieved of their due diligence and ethical requirements merely because of the tax preparation setting.

To balance the desires of the VITA program and the integrity of the accounting profession, the IRS should acknowledge the complexity of the VITA program and provide resources that are not based on speed and number of returns processed for its grant funds. Instructors should be encouraged to apply the due diligence and ethical standards required by Circular 230 and the other IRS publications and pronouncements discussed in this paper. Preparing the students to move past a mere understanding of the tax law to actual application of the law will help enhance the students learning experience and, potentially, their future career choices. More accurate return preparation is beneficial to the IRS as the number of return errors will be reduced, potentially helping recover millions of dollars in overpaid refunds. A commitment to due diligence and ethics will also enhance the accounting profession as more college graduates will be exposed to the proper way to handle challenging tax situations. Applying the same level of due diligence at university VITA sites should be encourage by the university, the VITA partners and the IRS.

\section{REFERENCES}

Accounting Degree.com. (2018). Professor. Retrieved from http://www.accountingdegree.com/professor/ Behn, B.K., Ezzell, W.F., Murphy, L.A., Rayburn, J.D., Stith, M.T., \& Strawser, J.R. (2012). The Pathways Commission on Accounting Higher Education: Charting a National Strategy for the Next Generation of Accountants. Issues in Accounting Education, 27, 595-600. doi: $10.2308 /$ iace- 10300

Berry, K. (2013, November 6). TIGTA Advises IRS Tax Prep Volunteers to Step Up. Retrieved from https://www.accountingweb.com/tax/irs/tigta-advises-irs-tax-prep-volunteers-to-step-up

Blanthorne, C., \& Westin, S. (2016). VITA: A Comprehensive Review of Literature and an Analysis of the Program in Accounting Education in the US. Issues in Accounting Education, 31(1), 51-69. doi: 10.2308/iace-51243

Christensen, A., \& Woodland, A. (2016). Is Participation in the Volunteer Income Tax Assistance (VITA) Program Associated with Students' Problem-Solving Skills and Professional Commitment? Issues in Accounting Education, 31(1), 71-90. doi: 10.2308/iace-51197

Christensen, A., \& Woodland, A. (2018). An Investigation of the Relationships Among Volunteer Income Tax Assistance (VITA) Participation and Ethical Judgment and Decision Making. Journal of Business Ethics, 147, 529-543. https://doi.org/10.1007/s10551-015-2957-x

Davis, A., Harrison, K., \& Turner, L. (2010). Practical guidance for establishing or improving a Volunteer Income Tax Assistance (VITA) program. The CPA Journal, 80(7), 59+.

Department of the Treasury. (2014, June). Treasury Department Circular No. 230. Retrieved from https://www.irs.gov/pub/irs-pdf/pcir230.pdf

Government Accountability Office. (2016, April). 2016 Annual Report. Retrieved from https://www.gao.gov/assets/680/676473.pdf

Government Publishing Office. (1997, June 18). Volunteer Protection Act of 1997. Retrieved from https://www.gpo.gov/fdsys/pkg/PLAW-105publ19/pdf/PLAW-105publ19.pdf

Internal Revenue Code. (2018). Title 26, Section 7701.

IRS. (2014, January 23). Part 25 Fraud Handbook. Irs.gov. Retrieved from https://www.irs.gov/irm/part25/irm_25-001-001 
IRS. (2015, April). VITA Grant Program Overview and Application Instructions. Retrieved from https://apply07.grants.gov/apply/opportunities/instructions/oppVITA-2016-cfda21.009-cidVITA2016-instructions.pdf

IRS. (2017). Form 1095 A. Irs.gov. Retrieved from https://www.irs.gov/pub/irs-pdf/f1095a.pdf

IRS. (2017, August 1). EITC and other refundable credits. Irs.gov. Retrieved from https://www.eitc.irs.gov/tax-preparer-toolkit/frequently-asked-questions/fraud/fraud

IRS. (2017, December). IRS Pub 4012. Irs.gov. Retrieved from https://www.irs.gov/pub/irs$\mathrm{pdf} / \mathrm{p} 4012 . \mathrm{pdf}$

IRS. (2017, October). Publication 4491. Irs.gov. Retrieved from https://www.irs.gov/pub/irspdf/p4491.pdf

IRS. (2018). Pub 49612017 Returns. Irs.gov. Retrieved from https://www.irs.gov/pub/irs-pdf/p4961.pdf

IRS. (2018). Refundable Credit Due Diligence Law. Irs.gov. Retrieved from https://www.eitc.irs.gov/taxpreparer-toolkit/preparer-due-diligence/due-diligence-law/eitc-due-diligence-law-and-regulation

IRS. (2018, April 18). ITIN reminders for Tax Professionals. Irs.gov. Retrieved from https://www.irs.gov/individuals/international-taxpayers/individual-taxpayer-identificationnumber-itin-reminders-for-tax-professionals

IRS. (2018, June 5). Free Tax Return Preparation for Qualifying Taxpayers. Retrieved from https://www.irs.gov/individuals/free-tax-return-preparation-for-you-by-volunteers

IRS. (2018, March 27). IRS Tax Volunteers. IRS.gov: https://www.irs.gov/individuals/irs-tax-volunteers

IRS. (2018, May 21). General ITN information. Retrieved from irs.gov. Retrieved from https://www.irs.gov/individuals/international-taxpayers/general-itin-information

Levin, A. (2016, April 6). Tax Indentity Theft: Why you are Vulnerable. ABC News. Retrieved from https://abcnews.go.com/Business/tax-identity-theft-youre-vulnerable/story?id=23183183

Miller, W., \& Thalacker, B. (2013). Development of an Award Winning Volunteer Income Tax Assistance Program: A Case Study. American Journal of Business Education, 6(5), 539. DOI:10.19030/ajbe.v6i5.8044

Overbaugh, R.C. (1990s). Blooms Taxonomy. fitnyc.edu. Retrieved from https://www.fitnyc.edu/files/pdfs/CET_TL_BloomsTaxonomy.pdf

Piton Foundation. (2018). Gary Community.org. Earned Income Tax Credit. Retrieved from http://www.garycommunity.org/piton/eitc

Quinn, J.G. (1995). Revitalizing VITA to address AECC position statement No. 1 Objectives. Journal of Accounting Education, 13(4), 479-497.

Thomson Reuters Tax and Accounting. (2015, November 18). IRS Commisioner details how taxpayers handled ACA provisions on their 2014 returns. tax.thompsonreuters.com. Retrieved from https://tax.thomsonreuters.com/media-resources/news-media-resources/checkpointnews/healthcare/irs-commissioner-details-how-taxpayers-handled-aca-provisions-on-their-2014returns/

Treasury Department Circular No. 230. (June 12, 2014). Regulations Governing Practice before the Internal Revenue Service. Department of the Treasury.

Treasury Inspector General for Tax Administration (TIGTA). (2014, September 29). Existing Compliance Processes Will Not Reduce the Billions of Dollars in Improper Earned Income Tax Credit and Additional Child Tax Credit Payments. Treasury.gov/tigta. Retrieved from https://www.treasury.gov/tigta/auditreports/2014reports/201440093fr.pdf

Westin, C.B. (2016). A Comprehensive Review of the Literature and an Analysis of the Program in Accounting Education in the U.S. Issues in Accounting Education, 31(1), 51-69. https://doi.org/10.2308/iace-51243 